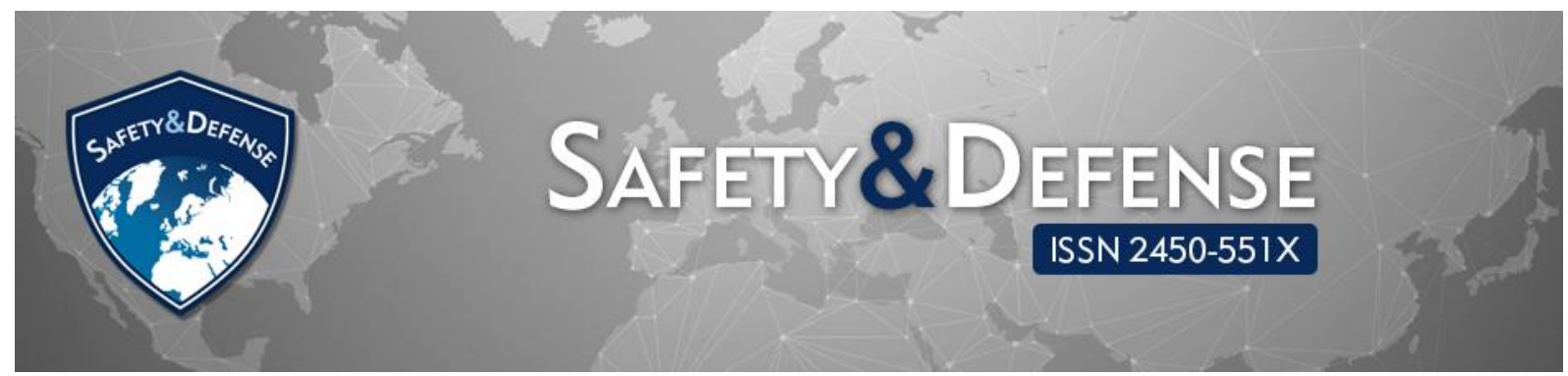

\title{
Unmanned Aircraft Systems in Crisis Management in Poland After 2007
}

\author{
Wojciech Krasiński \\ Siedlce University of Natural Sciences and Humanities, Siedlce, Poland \\ wojciech.krasinski@lipsko.eu, ORCID: 0000-0003-4041-2598
}

DOI: https://doi.org/10.37105/sd.79

\begin{abstract}
This article discusses the employment of unmanned aircraft systems in crisis management in Poland after 2007. The conceptual framework and organization of crisis management in Poland is presented as an introduction to further discussion. This article then analyses capabilities of various categories of unmanned aircraft systems taking into account specific requirements of crisis management. This article also points at preliminary lessons learned from employment of unmanned aircraft systems for crisis management in Poland in recent years. Due attention is paid to missions and the organization of employment of unmanned aircraft systems in crisis management operations. Perspectives of employing unmanned aircraft systems in crisis management are presented in the final part of the article.
\end{abstract}

Keywords: unmanned aircraft systems, crisis management, safety, Poland.

\section{Introduction}

Unmanned aircraft systems offer unique capabilities to crisis management as they in- crease the safety of rescue teams and the effectiveness of overall response to crisis situations. Unmanned aircraft systems have traditionally contributed to situational awareness by surveillance missions, but the scope of their employment in crisis management is expanding nowadays. Unmanned aircraft 
systems have been used for crisis management in Poland for a few years now. With technology evolving rapidly, and the accumulation of preliminary observations, it is good time to explore the topic as it is timely and directly related to the safety of citizens. The article introduces conceptual framework of crisis management in Poland and discusses the capabilities of unmanned aircraft systems in the context of requirements related to crisis management. Preliminary lessons learned from unmanned aerial vehicles' employment in crisis management in Poland are presented and serve as a point of departure for discussion on the future of the use of such systems in crisis management. This article aims at a preliminary assessment of unmanned aircraft systems' employment in crisis management in Poland after 2007. The topic is new in Poland. While there is plenty of research on crisis management in Poland, only a few research papers have been devoted to the employment of unmanned aircraft systems in crisis management in Poland. However, there are no monographic scientific analyses in the field of lessons observed yet. Research papers published in Polish after 2016 focus almost exclusively on the employment of unmanned aircraft systems in firefighting operations. The employment of such systems in crisis management in Poland has been mentioned in official press releases, internet news and publicly available documents related to crisis management. Therefore, a preliminary analysis and assessment of the employment of unmanned aircraft systems in crisis management in Poland seems desirable and may be viewed as a departure point to further research in this field.

\section{Conceptual framework for crisis management in Poland}

Political changes in Poland in the 1990s meant that more and more importance was attached to non-military threats. The experience of the 1997 "millennial" flood and adoption of the Act on the State of Natural Disaster in 2002 provided basic assumptions for the conceptual and legal framework related to crisis management in Poland. Poland's accession to NATO in 1999 and the European Union in 2004 accelerated the implementation of new solutions within the crisis management system in Poland that were needed for an effective response to non-military threats. Finally, the most comprehensive regulations in the field of crisis management entered into force with the adoption of the law on crisis management in 2007. A 'crisis situation' has been defined in Poland as a phenomenon adversely affecting the level of people's safety, constituting a threat to the property of considerable size or to the environment, and causing significant restrictions in the operations of public administration. The act on crisis management that was adopted in April 2007 defines crisis management as the activity of public administration authorities that constitutes an element of managing the national security management system. In accordance with the act regulations, crisis management activities consist of: preventing crisis situations, preparing to take control over them by way of planned activities, responding in the case of emergencies, removing their effects and reconstructing resources and critical infrastructure (RCB, 2020). In 2013, the comprehensive risk assessment for crisis management was completed and implemented into crisis management plans in Poland. It provided a catalogue of natural and man-made hazards, and assessed their possible impact through the lens of the probability of occurrence and severity of consequences. Since 
that time, flooding has been constantly assessed as one of the most frequent natural hazard that results in serious consequences for citizens, property and environment (RCB, 2013). Hurricanes and extremely high temperatures causing fires have been more frequent in recent years, requiring more attention within crisis management system. The crisis management system in Poland is characterized by a vertical structure of management by public administration. The span of management stretches down from the Prime Minister, through individual ministers, voivodship governors, and county mayors down to commune heads and city presidents. The Ministry of the Interior and Administration plays a major role in crisis management system as it supervises the activities of, among others, the Police, Border Guard, State Fire Service, and National Civil Defense. Crisis management in Poland is based on the principle of primacy of the territorial system. It means that the response to crisis situations is based on the territorial division of the state into municipalities, counties and voivodships up to the territory of the country. Depending on the scale of the crisis, the authority in charge for crisis response is the commune head (mayor, president), county mayor, the voivodship governor or the Prime Minister. Depending on the needs related to crisis response, the voivodship governors may request the support of the Armed Forces of the Republic of Poland. The routine response to crisis situations in Poland is the primary responsibility of the entities of the National Firefighting and Rescue System, Police, units of the State Medical Rescue Service, the Border Guard and other competent state offices, agencies, inspections, guards and services (SienkiewiczMałyjurek, and Krynojewski, 2010). The National Firefighting and Rescue System has been organized mainly on the basis of the State Fire Service and, to a lesser extent, volunteer fire brigades (Włodarski, 2018). The mission of the State Fire Service related directly to crisis management is to protect life, health, property, and the environment against fires, natural disasters or other local threats (Michailiuk, 2015). The leading role of the State Fire Service in crisis management in Poland is primarily due to the specialized equipment, knowledge, experience and skills that the servicemen of this formation have at their disposal (Gromek, 2017).

\section{Unmanned aircraft systems' capa- bilities and crisis management}

Public perception of unmanned aircraft systems is tied strongly to "drones" and focuses almost solely on the aerial vehicle. That is not true in terms of the complexity of unmanned aircraft systems employment or capabilities which they offer for crisis management. The term unmanned aircraft systems is much broader than unmanned aerial vehicles. It is defined as a system whose components include the unmanned aircraft, the supporting network and all equipment and personnel necessary to control the unmanned aircraft. Unmanned aircraft systems include remotely piloted aircraft, as well as ground control and support components. The lack of crew onboard such aircraft offers unique capabilities for crisis management, as it keeps rescue personnel safe outside the danger zone. Unmanned aircrafts may be smaller and cheaper to perform the same mission as a manned platform as they do not need to carry a human onboard or meet strict safety certification requirements. As unmanned aircraft systems operate within close vicinity of the crisis response action area, they may be more responsive than manned aircraft and stay longer in the air. Unmanned systems are also less vulnerable to limitations in visibility, which limit take off, operations and landings of manned aircraft (Cieślak et al., 2014). For crisis management purposes, the missions of un- 
manned aircraft systems are similar to piloted platforms. Unmanned systems are best suited for intelligence, surveillance and reconnaissance missions (Urząd Lotnictwa Cywilnego, 2013). They are a proven asset for search and rescue operations both during crisis situation and under normal conditions (Półka, et al., 2017). As such systems are equipped with daylight and thermal observation systems, and some of them even with radars, they may be used for both a wide area surveillance and pin-point detection of a broad spectrum of objects of interests to crisis management authorities and rescue teams. The key capability of unmanned aircraft systems for intelligence, surveillance and reconnaissance missions is tied to a near real-time transmission of imagery to ground stations, both point to point or in a broadcast mode. Thanks to that, data obtained by unmanned aircraft systems may be exploited in a timely manner by rescue teams and contribute to situational awareness at higher echelons of crisis management command and control. The spectrum of unmanned aircraft system tasks is related to a specific type of natural disasters or manmade catastrophes. During flooding surveillance aircraft systems can provide a real-time overview of the spread of floods, water levels at levees, and associated potential hazards for rescuers and surrounding communities (Kostur et al., 2019) . Similar actions can be taken with unmanned aircraft systems in the event of fires and search and rescue operations. The COVID 19 pandemic has proved that unmanned aircraft systems may also be used for measuring body temperature from a distance, as well as tracking and identifying people who do not comply with certain sanitary restrictions. Unmanned aircraft systems equipped with loudspeakers can be used for alerting the population about threats. This may improve evacuation efforts and improve communication between crisis management authorities and the community. Mini unmanned aircraft systems, especially vertical takeoff and landing systems may be used in urban areas affected by floods or even inside facilities that have suffered a construction collapse. In case of NCBR events, unmanned aircraft systems may be used to measure contamination, locate leaks of toxic substances, monitor areas of particularly dangerous industrial plants and check radiation around borders adjacent to nuclear power plants (Tuśnio, and Nowak, 2016). Larger unmanned aircraft systems may be employed for transportation missions. They may carry specialized rescue equipment appropriate to the mission being carried out. It is possible for unmanned aircraft systems to carry a rescue container for people effected by natural disasters such as floods or hurricanes, and to deliver the aid precisely. Thus such systems will be capable of reducing the time of providing a person in need with preliminary assistance before the rescue teams arrive at the scene (Borkowski, 2018). Possible payloads of unmanned aircraft systems may include first aid kits, medicines, medical equipment or personal protective equipment. Unmanned systems may deliver such supplies to hard-to-reach and particularly dangerous places without exposing rescue teams to unnecessary safety risk. It is also possible to use unmanned aircrafts to assist in decontamination in the event of an epidemic. The use of unmanned aircraft systems also has its economic justification. Although purchasing such systems seems expensive at the beginning, operating them is much cheaper than manned aircraft operations. Small unmanned aircraft systems are relatively easy to operate and the training costs are low. Finally, they may be easily integrated with rescue teams at lowest levels providing them with organic surveillance and reconnaissance capabilities. The loss of an aerial vehicle during crisis management operations does not bear serious consequences and by no means may be compared with a loss of a manned aircraft. 


\section{Lessons observed}

Recent years have seen more and more frequently increasingly extreme natural hazards, such as flooding, hurricanes or fires. The scale of natural disasters usually precluded effective conduct of crisis management, to include rescue operations, by local territorial self government authorities. Due to the scale of disasters and short warning time, the authorities needed external support from both civilian rescue services and military forces. The flood of May and June 2010 on the Wisła, Odra and Warta rivers directly impacted two percent of Poland's territory and required several thousands of rescue professionals to deal with disaster. The storms of August 11 and 12, 2017 were accompanied by the hurricane of the century, that instantly caused losses in several voivodships along three hundred kilometers wide swath of multi-cell line thunderstorms. Climate change, with higher average temperatures and decreasing precipitation have increased the risk of wild fires in forests and on pastures across Poland. An example may be the fire of 2020 in the Biebrzanski National Park, in which more than 52 square kilometers of grass and peatlands burnt. The effects of the fire were increased by prolonged droughts. Finally, the COVID 19 pandemic challenged Polish law enforcement, crisis management authorities and rescue teams with a number of issues. The need for effective enforcement of quarantine, restrictions of movement or gathering serve just as example. All those situations prove the importance of employing unmanned aircraft systems in crisis management. The State Fire Service in Poland started operating first unmanned aircraft systems that could be employed in crisis management in 2011 thanks to the support of the European Union's funds. Until the end of 2015, the State Fire Service had only eight unmanned aircraft systems. This changed in 2019 with large scale purchases of dedicated unmanned aircraft systems. The State Fire Service acquired fifteen Yuneec Typhon $\mathrm{H}_{52}$ and eleven DJI Matrice 200 systems. Both systems are equipped with daylight cameras, and the DJIs also carry infrared cameras. The systems are capable of real life transmission of imagery to ground control stations (InfoSecuritu24, 2019). In 2019, the Police bought thirty eight DJI Matrice 210v2 and DJI Matrice 200v2. unmanned aircraft systems for PLN 5.6 million (BRD24, 2019). Prior to the COVID 19 pandemic, the unmanned aircraft systems supported routine operations of the State Fire Service and the Police. Some lessons about unmanned aircraft systems' capabilities were gathered during crisis management exercise. In 2018, exercises were carried out using unmanned aircraft systems based on the scenario of a potential flood related situation in Wroclaw with elevated water levels on the Odra River (Straż Wrocław, 2018). Between 2018 and 2020, the State Fire Service used unmanned aircraft systems to locate fire sources, contaminated spots on the water surface, obtain spatial data in the event of a flood, and to search for missing people in debris. Real life employment of unmanned aircraft systems in crisis management took place in March and April 2020. Territorial Defense Forces used FlyEye unmanned aircraft systems to monitor fires in the Biebrzanski National Park. Broad area airborne surveillance proved critical in a swampy terrain that was hard to access by ground firefighting units. Unmanned aircraft systems equipped with infrared cameras provided timely and precise data for the commanders of the firefighting teams services. They were also employed at night, when they successfully located fire outlets, and assisted the movement of firefighting units (Radar, 2020). Since March 2020, the governmental and territorial self government authorities have used unmanned aircraft systems for crisis management activities related to COVID 19 pandemics. The Police have been using such systems for monitoring wide areas and to 
augment ground patrolling. The Polish Air Navigation Services Agency initiated the coordination of the possible employment of privately owned aircraft systems to monitor the situation related to the COVID 19 pandemic. More than 750 operators willing to help responded. The capabilities of Poland's produced unmanned aircraft systems were demonstrated to governmental and territorial self government at the beginning of the disease outbreak. The Flytronic company offered the support of its unmanned aircraft systems to assist response to the COVID 19 pandemic. The FlyEye systems developed by Flytronic demonstrated the establishment of a voice communication and video transmission system for all crisis management services, which might be employed in observing hard-to-reach areas requiring surveillance in connection with COVID 19 disease. In addition, FlyEye MED, an unmanned system that provides support to all medical services capable of delivering medicines and other medical supplies over a distance of up to 50 kilometers, was presented (Świat Dronów, 2020a). The state Police along with municipal guards have been using unmanned aircraft systems to monitor public spaces. Aerial surveillance were used among other cities including Bydgoszcz, Lublin, Kraków, Szczecin, Siemianowice Ślaskie and Zielona Góra (Świat Dronów, 2020b). The unmanned aircraft systems assistance to law enforcement and public order services have proved efficient and invaluable. On 29 April 2020, the first autonomous flight of Polish Hermes V8MT unmanned aircraft system with a transport module took place in Warsaw. It was the first such flight in Europe. Samples for COVID 19 testing were transported between two hospitals in Warsaw. The flight proved capability of the unmanned aircraft systems to replace ambulance vehicles in such a service and free them for transporting patients. Unmanned aircraft systems made several rounds between Warsaw hospitals and the tests were successful (Spartaqs, 2020). In May 2020, preparations were made in Sosnowiec to use unmanned aircraft systems to disinfect bus stops in the city (Cyfrowa, 2020).

\section{The future of unmanned aircraft systems' employment in crisis management in Poland}

The growing commercial sector of unmanned aircraft systems in Poland, including both producers and service providers, allows for rather optimistic foresight related to the employment of such systems in crisis management. In recent years, the Polish Development Fund in cooperation with the Ministry of Infrastructure, the Polish Air Navigation Services Agency and the Civil Aviation Office has been implementing a program that is to support the development of the unmanned aircraft system production in Poland. Poland is one of the regional leaders in developing infrastructure that allows managing unmanned aircraft systems traffic management throughout the national airspace with the use of the PansaUTM system and respective legal regulations tailored specifically for unmanned systems (PANSA, 2020). According to the announcement of the Minister of Infrastructure of 2019 and the standards developed by the Polish Air Navigation Services Agency, Poland has introduced one of the first regulations in the world that allows for flexible unmanned flights, i.e. Beyond Visual Line Of Sight (BVLOS) and fully automatic flights of unmanned aircraft systems. With such technological and procedural solutions in place, there is a growing potential for the employment of unmanned aircraft systems as part of crisis management efforts. Enabling BVLOS flights of unmanned systems will, in the long term, improve broad area surveillance. It will greatly increase situational awareness and safety of ground rescue teams during fires, flooding or chemical, biological, radiation, nuclear (CBRN) events (Salmoral, 
et al., 2020). BVLOS operations will speed up assistance to people in need, especially in hard-to-reach places and increase the safety of rescue teams. In the future, the Police plans to use unmanned aircraft systems to detect illegal firing of grasses leading to fires (Świat Dronów, 2020c). With almost no experience of using unmanned aircraft systems for aerial delivery so far, one may expect dynamic increase in such tasks for unmanned aircraft systems in crisis management in Poland in near future. Following the experience of other countries, such as France, Iran, Spain and Greece, unmanned aircraft systems may be used for helping to supply lifesaving equipment to people in need. They may also resupply rescue teams. It is too early to discuss the scope of the use of unmanned aircraft systems in pandemic scenarios in Poland. Depending on results of trials in Sosnowiec, we may see increasing use of unmanned systems for disinfection of public infrastructure in cities. It is technically feasible to measure the body temperature of people and use unmanned aircraft systems to enforce sanitary regimes (Cyfrowa, 2020). So, it seems fair to argue that law enforcement and rescue services along with crisis management authorities will be tempted to use this capability more often. In the future, the challenge for the employment of unmanned aircraft systems in crisis management will be tied to increasing automation of their operations to reduce number of people needed to operate them. With broad area surveillance capability limited to unmanned aircraft systems of the Armed Forces of the Republic of Poland and the Border Guard, it will be necessary to improve civil-military cooperation and interagency coordination to make the best of their employment in civilian led crisis response actions. A community of about twenty thousand professional private operators of unmanned aircraft systems in Poland needs due attention to integrate them into crisis management along with state rescue services. Although use of privately owned "drones" may be of assistance in crisis management, one must be cautious about appropriate level of training of volunteer operators of unmanned aircraft systems and safety during rescue operations.

\section{Conclusions}

Natural disasters have been occurring in Poland more and more frequently in recent years. Such threats to society's safety requires timely and effective response through crisis management operations. Unmanned aircraft systems offer unique capabilities that may be useful in crisis management. They may be employed for broad area surveillance of natural disasters and execution of tasks in hazardous places. Unmanned aircraft systems reduce the danger to life and health of rescue personnel involved in crisis management operations. The use of unmanned aircraft systems in crisis management in Poland has just started. Until now, unmanned aircraft systems have been used for monitoring threats. However, taking into account even preliminary observations and lessons in the field of employment of unmanned aircraft systems in crisis management, it can be seen that these are tools with high potential. In the coming years, unmanned aircraft systems may replace manned aircraft in a number of tasks related to crisis management. While it is too early to propose specific solutions that need improvement, the issue of the deconfliction and integration of unmanned aircraft systems in crisis management will grow in importance. With the development of visions of unmanned aircraft systems' employment in crisis management, it is also important to create very precise rules and procedures that will enable the best use of the potential that those systems bring to rescue efforts. 


\section{References}

1. Borkowski, R., (2018). Bezpieczeństwo. Teoria i praktyka. Ratownictwo i medycyna katastrof w reagowaniu kryzysowym, Kwartalnik Krakowskiej Akademii im. Andrzeja Frycza Modrzewskiego, No. 2 (XXXI), p. 125.

2. BRD24, Polska policja kupiła dorny za blisko $6 \mathrm{mln}$ zł. 19.12.2019. http://www.brd24.pl/spoleczenstwo/po lataja-nad-kierowcami-polska-policjakupila-drony-za-blisko-6-mln-zl/, 30.05.2020.

3. Cieślak, E., Zieliński, T., Grenda, B., Rosłan, G., Żyłka, D., Kuptel, A., Markiewicz, T., Marud, W., (2014). Operacyjne aspekty rozwoju i wykorzystania bezzałogowych systemów powietrznych w Polsce, Akademia Obrony Narodowej, p. 10.

4. Duszczyk, M., Cyfrowa rp.pl, Polski latający termometr pomoże w walce $\mathrm{z}$ koronawirusem, 26.04.2020.

https://cyfrowa.rp.pl/technologie/46341-latajacy-termometr-pomozew-walce-z-wirusem, 31.05.2020.

5. Duszczyk, M., Cyfrowa rp.pl, Pandemia przyśpieszyła rewolucję w przestrzeni powietrznej w naszym kraju. Drony będą przewozić testy na Covid-19, dezynfekować przystanki autobusowe czy... mierzyć temperature przechodniów. 26.04.2020. https://cyfrowa.rp.pl/technologie/46341-latajacy-termometr-pomozew-walce-z-wirusem, 31.05.2020.

6. Gromek, P., (2017). Państwowa Straż Pożarna a zarządzanie kryzysowe. Ujęcie strukturalne, Zeszyty Naukowe Szkoły Głównej Służby Pożarniczej w Warszawie, No 63/3/2017, p. 32.

7. Kostur, K., Żmigordzka M., Balcerzak T., Bezzałogowe statki powietrzne w ochronie przeciwpożarowej. (2019). https://www.eumed.net/rev/rednma/36/aerial-vehicles.html, 31.05.2020, p. 42-43, 58-60.

8. Kozubal, M., Radar Wojsko Polskie, Bezzałogowce szukają źródeł ognia.
23.04.2020. https://www.rp.pl/RADAR-Wojsko-Polskie/304239939-Bezzalogowce-szukaja-zrodel-ognia.html, 28.04.2020.

9. Michailiuk, B., (2015). Miejsce ochrony ludności i ratownictwa w systemie bezpieczeństwa narodowego Rzeczypospolitej Polskiej, „Zeszyty Naukowe WSEI”, seria: Administracja, No 5 (1), p. 285.

10. Mieszała, T., Straż Wrocław, Ćwiczenia taktyczno-bojowe „ODRA-2018”. (2018). http://straz.wroclaw.pl/cwiczenia-taktyczno-bojowe-odra-2018/, 29.04.2020.

11. Pansa, PansaUTM. https://www.pansa.pl/pansautm/, 26.05.2020.

12. Półka, M., Ptak, Sz., Kuziora, Ł., The use of UAV's for search and rescue operations. (2017). https://www.sciencedirect.com/science/article/pii/S1877705817326759, 01.06.2020.

DOI: https://doi.org/10.1016/j.proeng.2017.06.129, p. 2.

13. Rachwalska, M., InfoSecurity24, Do kogo trafią strażackie drony?. 4.06.2019. https://www.infosecurity24.pl/komenda-glowna-psp-rozdziela-drony, 27.04.2020.

14. RCB, Act of 26 April 2007 on Crisis Management. https://rcb.gov.pl/wp-content/uploads/WERYF -ACT Crisis Management English-1.pdf, 31.05.2020.

15. Salmoral, G., Rvias Cascado, M., Muthusamy, M., Butler, D., Menon, P.P., Leinster, P., Guidelines for the Use of Unmanned Aerial Systems in Flood Emergency Response. (2020). https://www.mdpi.com/20734441/12/2/521/htm, 01.06.2020. DOI: https://doi.org/10.3390/w12020521, pp. 2 - 17.

16. Sienkiewicz-Małyjurek, K., Krynojewski, F. R., (2010). Zarządzanie kryzysowe w administracji publicznej. Wydanie II, Difin SA Warszawa, p. 51. 
17. Spartaqs, Zagraniczne media o locie transportowym Dronoida HERMES V8MT pomiędzy warszawskimi szpitalami. 28.05.2020. http://spartaqs.com/media-o-nas-cat/zagranicznemedia-o-locie-transportowym-dronoida-hermes-v8mt-pomiedzy-warszawskimi-szpitalami/, 31.05.2020.

18. Świat Dronów, Systemy bezzałogowe grupy WB w walce $\mathrm{z}$ koronawirusem. (2.04.2020a). $\quad$ http://www.swiatdronow.pl/systemy-bezzalogowe-grupywb-w-walce-z-koronawirusem, 29.04.2020.

19. Tuśnio, N., Nowak, A., (2016). Bezzałogowe statki powietrzne $\mathrm{w}$ działaniach Państwowej Straży Pożarnej - propozycja dedykowana dla Państwowej Straży Pożarnej. Zeszyty Naukowe SGSP 2016, no 58 (vol. 1)/2/2016, pp. 119-120.

20. Urząd Lotnictwa Cywilnego. (2013). Zespół do spraw bezzałogowych statków powietrznych, Bezzałogowe statki powietrzne w Polsce. Warszawa, p. 2.

21. Włodarski, A. J., (2018). Współdziałania międzyorganizacyjne w ochronie ludności (ujęcie retrospektywne). Szkoła Główna Służby Pożarniczej, p. 66. 